\title{
Imperforate hymen: the importance of early diagnosis
}

\author{
Pedro Vieira Enes ${ }^{1 *}$, Pedro Brandão ${ }^{1}$, Paula Ramôa ${ }^{2}$, Ana Torgal ${ }^{1}$
}

${ }^{1}$ Centro Hospitalar Tâmega e Sousa, Penafiel, Porto, Portugal

${ }^{2}$ Hospital Lusiadas, Porto; Porto, Portugal

Received: 14 April 2017

Accepted: 08 May 2017

\section{*Correspondence:}

Dr. Pedro Vieira Enes,

E-mail: pedrovieiraenes@gmail.com

Copyright: () the author(s), publisher and licensee Medip Academy. This is an open-access article distributed under the terms of the Creative Commons Attribution Non-Commercial License, which permits unrestricted non-commercial use, distribution, and reproduction in any medium, provided the original work is properly cited.

\begin{abstract}
The imperforate hymen is one of the most common obstructive lesions of the female genital system, with a prevalence from 1: 1000 to 1: 10000. Anomalies of the hymen are due to incomplete degeneration of the hymen central portion. It can be diagnosed at physical examination from birth and treated surgically. The most common clinical presentation is cyclic pelvic abdominal pain, urinary retention and hematocolpos. 12-year-old girl, premenarche who appealed to the Emergency department with abdominal pain and bilateral lumbar irradiation, over 2 weeks of evolution. Physical examination showed abdominal tumefaction in the hypogastric region, painful to palpation and under tension. Gynecological examination revealed an imperforate hymen, protruding from the introitus. Rectal ultrasonography performed at the emergency room showed vaginal distension with a hypoechoic content of $16 \mathrm{~cm}$, larger diameter. Surgical hymenectomy was performed as treatment. On the 58th postoperative day, the patient was asymptomatic. The authors present a clinical case of imperforate hymen diagnosed at menarche, an anomaly diagnosed increasingly early due to the earlier physical examination that involves observation of the external genitalia of the new-born and the pre-pubertal child.
\end{abstract}

Keywords: Amenorrhea, Abdominal pain, Haematocolpos, Hymenectomy, Imperforate hymen

\section{INTRODUCTION}

The imperforate hymen is one of the most common obstructive lesions in female genital system, with a prevalence from 1:1000 to $1: 10000 .^{1,2}$ The vagina lower third has origin in the urogenital sinus. From the union of vagina's middle third will remain a membrane and after regression of its central portion will originate the hymen. This separates the urogenital from the vaginal cavity. The membrane of this structure is composed of connective fibrous tissue attached to the vaginal wall. When regression does not occur, the hymen is imperforate. The differentiation of the female genitalia is only completed around the 20th week after the end of the vaginal canalisation. Usually, hymen rupture occurs before birth due to degeneration of central epithelial cells. ${ }^{3,4}$ Hymen abnormalities result from incomplete degeneration of the hymen central portion. These anatomical variations include imperforate, microperforated, septate and cribriform hymen. These can be easily identified during physical examination of the female genitalia. ${ }^{5}$ Newborn physical examination includes hymen evaluation. ${ }^{6-8}$ Infants with imperforate hymen present prominent introits due to the mucocolpos presence, secondary to maternal estradiol circulating. ${ }^{6,9}$ After birth, the mucus is reabsorbed and the child will become asymptomatic until the menarche. With menarche, there will be blood accumulation in the vaginal cavity that results in the following symptomatology: cyclic abdominal $p e l v i c$ pain, low back pain, urinary retention sometimes with renal complications. $^{2,4,5,6,10}$ 


\section{CASE REPORT}

A 12-year-old Caucasian female patient was observed in the emergency department for abdominal pain, bilateral lumbar irradiation with 2 weeks of evolution. She reported an episode with similar symptoms about 1 month prior to this observation. She denied the occurrence of menstruation or sexual activity and had no relevant medical, surgical or family history. She was apyretic, blood pressure: $107 / 80 \mathrm{mmHg}$; Heart rate 82 b.p.m. Urinalysis without changes. Physical examination showed abdominal tumefaction in the hypogastric region, painful to palpation, under tension but without signs of peritoneal irritation. Gynecological examination revealed the presence of imperforate hymen, prominent introitus (Figure 1).

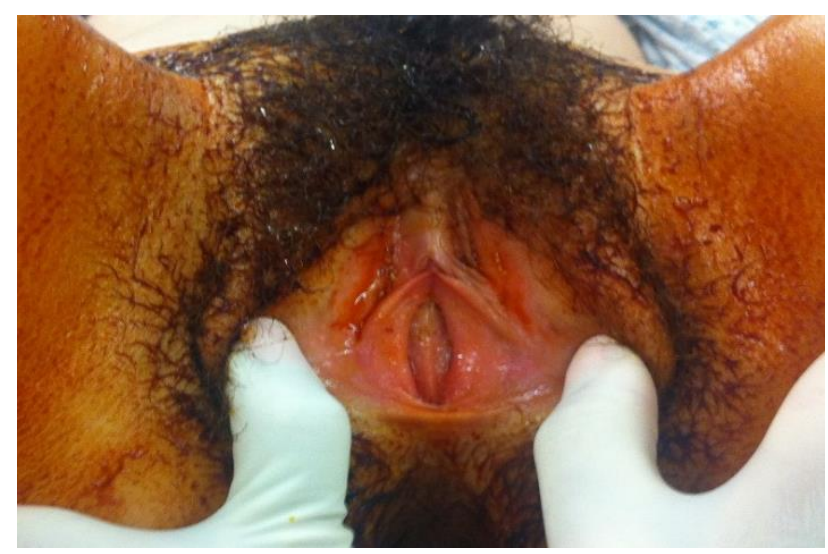

Figure 1: Imperfurate hymen.

At rectal and bimanual examination she had a distended vagina with bulging of the rectum anterior wall. Rectal ultrasound performed at the emergency department showed vaginal distension with hypoechoic content of 16 $\mathrm{cm}$, larger diameter, and residual hematometry. Ovaries did not present changes. Analytically there were no changes.

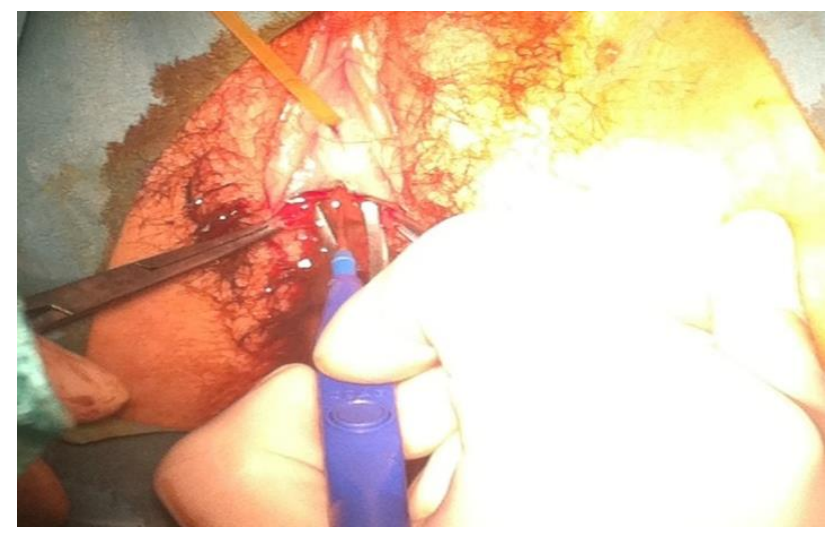

Figure 2: Himenectomy.

The patient underwent surgical treatment, hymenectomy. A cross-sectional incision was made continuously through the convexity of the membrane, draining approximately $400 \mathrm{~mL}$ of viscous dark brown fluid content suggestive of blood collected from probable catamenium (Figure 2).

The four triangular segments of the membrane were excised followed by sutures with separate stitches, with absorbable string, to bring the mucosa closer to the edges of the skin, in order to create a normal-sized orifice. The postoperative period was uneventful and the patient was discharged on the 2 nd day of hospitalization.

On the 58th postoperative day, the patient was asymptomatic, with regular menstrual cycles, interlude of 28 days, and catamenium of 5 days. At the gynecological examination, the surgical wound was healed without inflammatory signs (Figure 3).

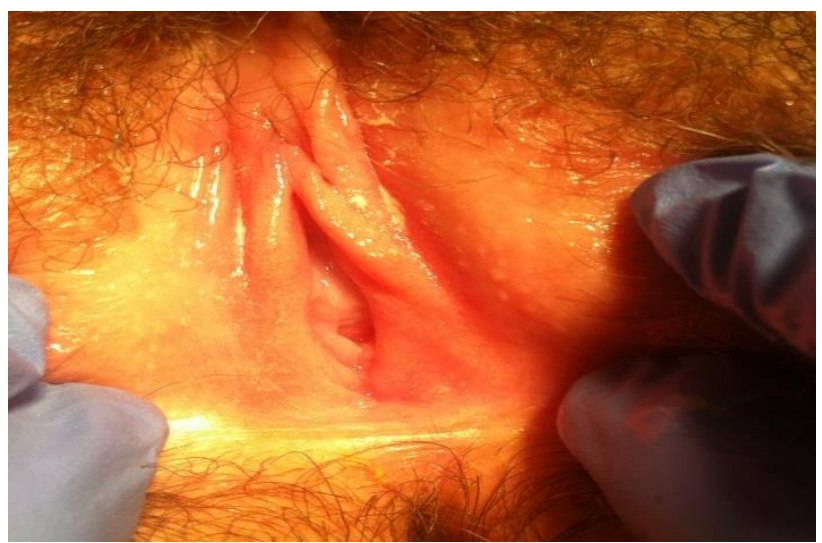

Figure 3: $58^{\circ}$ day after surgery.

\section{DISCUSSION}

Although genital malformations are infrequent, among them, imperforate hymen is the most common obstructive disorder. ${ }^{6}$ This anomaly can be easily diagnosed during the first months of life, presenting as a prominent mass at the introitus plane, gray color, visible, resulting from the acummulation of vaginal secretions produced by maternal estradiol - mucocolpos. , $7,8,11$ It can be diagnosed through a clinical history and physical examination. in an adolescent with cyclic abdominal pain, primary amenorrhoea and with obvious secondary sexual characteristics. As a result of the obstruction caused by the imperforate hymen, the patient may present symptoms related to the catamenium blood accumulation in the vagina (hematocolpos) and in the uterine cavity (hematometra). ${ }^{1,12}$ Hematocolpos can lead to urinary retention, constipation, low back pain and rarely in lower limb edema. 2,6,13 Laboratory and imaging tests are generally not necessary for the imperforate hymen classic forms diagnosis. However, ultrasound can be a useful tool in cases of doubt. ${ }^{1,2}$ Differential diagnosis should be made with other hymen anomalies, that are not imperfurate. In these, although there is no obstruction to the menstrual flow passage, its correct evaluation and orientation are important given the impact they can cause in the patient life, such as the inability to insert tampons, 
difficulty in intercourse and an increased risk of pelvic inflammatory disease. ${ }^{6,14,15}$

The imperforate hymen treatment is surgical. Although the hymenectomy can be performed at any age, it should be as early as possible. This surgical procedure aims to resolve the obstruction and create a normal dimensions hole. It is beneficial to stimulate estrogen prior to the surgical procedure. The prognosis is excellent. However, due to a low risk of recurrence, surveillance is necessary. ${ }^{2,11}$

\section{CONCLUSION}

The authors present a case of imperforate hymen case report diagnosed at the menarche. This entity is nowadays usually diagnosed earlier due to the early physical examination of the new-born and the prepubertal child that includes external genitalia observation. Early diagnosis is important to prevent complications such as infections, kidney, endometriosis and infertility.

\section{Funding: No funding sources}

Conflict of interest: None declared

Ethical approval: Not required

\section{REFERENCES}

1. Heger AH, Ticson L, Guerra L, et al. Appearance of the genitalia in girls selected for nonabuse: review of hymenal morphology and nonspecifi c fi ndings. J Pediatr Adolesc Gynecol. 2002;15:27-35.

2. Lacy JA, Hillard PA. Imperforate hymen. Emedicine [updated Feb 24, 2010]. (acedido em Outubro 2012). Disponível em: http://www.emedicine.medscape.com/article/269050 -overview.

3. The American Fertility Society classifi cations of adnexal adhesions, distal tubal occlusion, tubal occlusion secondary to tubal ligation, tubal pregnancies, müllerian anomalies and intrauterine adhesions. Fertil Steril. 1988;49:944.

4. Puerta-Fonollá AJ. Morphogenesis of the human genital tract. Ital J Anat Embryol. 1998;103:3-15.
5. Ulfelder H, Robboy SJ. The embryologic development of thehuman vagina. Am J Obstet Gynecol. 1976;126:769-76.

6. Shaw LM, Jones WA, Brereton RJ. Imperforate hymen and vaginal atresia and their associated anomalies. J R Soc Med. 1983;76:560-6.

7. Laufer MR, Weisman LE, Torchia MM, Emans SJ, Duryea TK. Gynecologic examination of the newborn and child. UptoDate [updated Fev 24, 2017]. (Acedido em Março 2017). Disponivel em www.uptodate.com

8. Drutz JE, Duryea TK, Torchia MM. The pediatric physical examination: The perineum. UptoDate [updated Jul 9, 2015] (Acedido em Dezembro 2016). Disponível em www.uptodate.com

9. Bakos O, Berglund L. Imperforate and ruptured hematosalpinx: a case report with a review of the literature. J Adolec Health. 1999; 24:226-8.

10. Salvat J, Slamani L. Hématocolpos. J Gynecol Obstet Biol Reprod. 1998;27:396-402.

11. Herman MI, Saxena AK, Paton EA. Imperforate hymen. Emedicine [updated Oct 2, 2009]. Disponivel em: http://emedicine.medscape.com/article/954252 overview.

12. Saravelos SH, Cocksedge KA, Li TC. Prevalence and diagnosis of congenital uterine anomalies in women with reproductive failure: a critical appraisal. Hum Reprod Update. 2008;14:415-29.

13. Liang CC, Chang SD, Soong YK. Long-term followup of women who underwent surgical correction for imperforate hymen. Arch Gynecol Obstet. 2003;269:5-8.

14. Salvat J, Slamani L. Hematocolpos. J Gynecol Obstet Biol Reprod (Paris).1998;27:396-402.

15. Nazir Z, Rizvi RM, Qureshi RN, Khan ZS, Khan Z. Congenital vaginal obstructions: varied presentation and outcome. Pediatr Surg Int. 2006;22:749-53.

Cite this article as: Enes PV, Brandão, Ramôa P, Torgal A. Imperforate hymen: the importance of early diagnosis. Int J Reprod Contracept Obstet Gynecol 2017;6:2628-30. 